\title{
New rules for gene patents
}

The US Patent and Trademark Office (PTO; Arlington, VA) is soon expected to release final guidelines that will be used to determine whether a gene-related patent will be granted by the office. Generally, the biotech industry and many professional groups welcome the new guidelines, agreeing that they sufficiently tighten standards for gene patents. But critics, including the US National Institutes of Health (NIH; Bethesda, MD), say the guidelines don't go far enough to prevent nonproductive patents, and are worried that researchers will be hindered by in effect having to pay a toll every time they want to probe a patented area of the genome.

The final guidelines are not expected to be substantially different from the December 1999 interim guidelines, which are already being used by PTO examiners. According to John Doll, director of biotechnology at PTO, the new utility requirements have three parts, and require that patent applicants show specific, credible, and substantial utility for gene sequences. Specific utility, Doll says, means the applicant has to know what the gene does. In the past, patenting of a gene sequence was allowed based on general claims such as using the sequence as a probe; now, such a general claim would be insufficient. Credible utility, Doll says, means that the claim must be believable based on current state of the art. He says that 10 years ago, a claim that a sequence could be a cure for cancer would not have been credible, but today scientific literature recognizes that some cancers can be "cured", and therefore that claim could be accepted. The final part, which is a new one, is substantial utility. This means that the sequence must have a real-world use, such as use as a diagnostic or a treatment for a disease. Doll says it is not enough to make a general utility claim such as using the sequence to make a protein, without giving a real-world use for that protein.

To date, about 6,000 gene-related patents have been issued in the US, and more than 1,000 of them are specifically related to human genes and human gene variations. About 20,000 applications related to gene patents are currently pending before PTO, and it is unknown how many will be rejected based on the new guidelines.

In mid-July, the US House Judiciary Committee's Subcommittee on Courts and Intellectual Property held an oversight hearing to explore issues related to gene patents and other genomic inventions, and the new guidelines were widely discussed. In his testimony, Todd Dickinson, director of PTO, explained that US patent law allows anything that is "made by man" to be patented, including genes that are isolated and purified from their natural environment. He said the "question of utility" therefore determines what can be patented, noting that patenting of raw DNA sequence data is not allowed.

Both Harold Varmus, former director of $\mathrm{NIH}$ and now president of Memorial Sloan-Kettering Cancer Center (New York), and Francis Collins, director of the National Human Genome Research Institute at NIH, have been critical of the proposed guidelines, saying that the utility requirement is not stringent enough to disallow patents that aren't productive. In his House testimony, Varmus explained that " $[\mathrm{u}]$ nder the new proposal, a patent could be issued for a gene or a portion of a gene based on still quite superficial and potentially misleading information about the properties of the gene or about how it might be used to diagnose, prevent, or treat disease." He said that "such apparently extensive rights might well discourage others from studying members of such gene families to achieve practical goals." Specifically, critics from NIH have said utility claims based on computer homology studies of gene sequences, and not actual research on the laboratory bench, are not sufficient for determining gene function. They say that the new standards should not allow claims of "predicted" function.

However, Andrea Ryan, president-elect of the American Intellectual Property Law Association (Arlington, VA) and associate general council at biopharmaceutical firm Genetics Institute (Cambridge, MA), says that legally there are no "good" and "bad" patents, and that anything that meets the requirements should be patentable.

In his hearing testimony at the House hearing, Randal Scott, president and chief scientific officer of Incyte Genomics (Palo Alto, CA), unsurprisingly concurred that patents should not be limited to gene sequences for which specific biological activity is disclosed.

Incyte currently holds about 500 patents in the US for full-length genes, and has applied for about 7,000-7,500 more. According to Lee Bendekgey, Incyte's general counsel, the majority of patents the company has filed for have been based on both homology and research on the tissues from which the sequences have been derived. He believes, based on the kinds of papers now being accepted for publication in scientific journals, that homology is adequate for defining credible utility, assuming that the homology studies are done properly and that class of genes the sequence is being compared to is well characterized. And he points out that under US law, showing that a utility is credible is enough, that it doesn't have to be proven to an absolute certainty.

Doll explains that under US law, PTO must assume that patent claims are true, and has the burden to disprove claims in order to reject them. He says there is no scientific evidence to reject claims solely because they are based on computer homology data. He notes that four times out of five, the computer models are correct, and explains that the patent system is "self-correcting"; if a utility turns out to be incorrect, the patent will be revoked.

However, in his hearing testimony, Dennis J. Henner, senior vice president for research at Genentech (S. San Francisco, $\mathrm{CA}$ ), supported the NIH view that "predictions of utility for a polypeptide based on homology alone will be extremely limited" and reiterated the need for biological assays to sufficiently characterize gene functions.

Genentech holds more than 3,600 patents worldwide and has another 2,600 pending, Of those pending, 1,000 are for novel, fulllength gene sequences. Sean Johnston, vice president of intellectual property at Genentech, says the company has always used the standard that a gene sequence and its protein must be isolated and the protein assayed for function before a patent is filed. Johnston argues that patents based on sequence homology do not meet the "credible" utility requirement based on current state of the art and therefore should not be granted. He adds that granting patents that later have to be reversed could result in problems with litigation, expensive and protracted reviews, and uncertainty in the marketplace.

Charles Ludlam, vice president for government relations at the Biotechnology Industry Organization (BIO; Washington, DC), points out that the types of cases being debated relate to only a very small portionprobably $2-3 \%$ - of all of the gene sequences patent applications. He says the real focus of debate is actually not on the guidelines per se, but on the accompanying training materials for patent examiners giving examples of how the guidelines will be interpreted. He believes that it is important for guidelines to be flexible to accommodate new, emerging science, and that it is up to patent examiners to rule on each sequence on a case-by-case basis.

Julie Grisham 